\title{
Yield Response of Cabbage ( Brassica oleraceae var. capitata) cv. Pride of India To Varying Levels of Chemical Fertilizers And Vermicompost
}

\author{
${ }^{1}$ K. Babyshila Devi, ${ }^{2}$ N. Irabanta Singh \\ ${ }^{1 \& 2}$ Aerobiology, Microbiology, Biotechnology and Plant Pathology Laboratory, \\ Department of Life Sciences, Manipur University, Canchipur- 795005, Manipur.
}

\begin{abstract}
Varying levels of chemical fertilizers i.e. NPK and vermicompost significantly influenced the yield attributing characters and growth and biomass production in cabbage (Brassica oleraceae var.capitata) cv. Pride of India. There were six treatments ( $T_{1}$ : control i,e without any fertilizer; $T_{2}: N P K$ @ 140:140:140 kg/ha; $T_{3}$ : NPK@105:105:105 kg/ha + Vermicompost @1 ton/ha; T4: NPK@70:70:70 kg/ha + Vermicompost @ 2tons/ha; T5:NPK@35:35:35 kg/ha + Vermicompost @ 3 tons $/ \mathrm{ha} ; T_{6}:$ Vermicompost @ 4 tons $/$ ha) each replicated four times. A maximum of $58.67 \%$ increase in yield over control was observed in a combined application of NPK and vermicompost in halves of their recommended doses.
\end{abstract}

Key Words: NPK, Vermicompost, recommended dose, Brassica oleraceae var. capitata, yield.

\section{Introduction}

During the last decade, organic agriculture has gained recognition as an alternative to the conventional practices. It aims at "cooperating rather than confronting with nature". It reduces cost of production, preserve the environment and protect human health by eliminating the use of toxic farm chemicals (Ambika and Kurian, 2004). Vermiculture biotechnology promises to usher in the 'second Green Revolution' by completely replacing the destructive agro chemicals which did more harm than good to both the farmers and their farmland (Sinha $e t$ al.,2010). Vermicompost or in situ vermiculture associated with other biological inputs have been applied to grow vegetables and other crops successfully. These approaches have been proved to be economical as well as productive

Vermicompost has a lower value of NPK than any standard chemical fertilizer (Tomlin, 1983). However the unique way in which vermicompost is produced, even right in the field and at low cost makes it very attractive for practical application (Talashilkar et al., 2003).

Application of vermicompost in crop production is an important aspect of organic farming and it finds a wide range of applications in various types of agricultural plants. Vermicompost can be used as an effective manure in crop production and biofertilizer in maintaining soil health (Edwards and Lofly, 1977; Lee, 1985). Kale (1996) and Ismail (2005) suggested vermicompost as an ideal biofertilizer for vegetable crops like brinjal, okra, tomato, cucumber etc. Studies on the effectiveness of vermicompost as an organic manure on the growth and yield of cabbage was reported (Mahendran and Kumar, 1997).

\section{Material And Method}

Experiments were conducted for three consecutive crop seasons (2006-07, 2007-08, 2008-09) in the garden of Life Sciences Department, Manipur University Campus to study the efficacy of vermicompost on the yield of Cabbage (Brassica oleraceae var.capitata) cv. Pride of India. There were six treatments $\left(\mathrm{T}_{1}\right.$ : control i,e without any fertilizer; $\mathrm{T}_{2}$ : NPK @ 140:140:140 kg/ha; $\mathrm{T}_{3}$ : NPK@ 105:105:105 kg/ha + Vermicompost @ 1 ton/ha; $\mathrm{T}_{4}$ : NPK@ 70:70:70 kg/ha + Vermicompost @ 2tons/ha; T 5 : NPK@35:35:35 kg/ha + Vermicompost @ 3 tons/ha; $\mathrm{T}_{6}$ : Vermicompost @ 4 tons/ha) each replicated four times.

One month old saplings were transplanted at a spacing of $60 \mathrm{X} 45 \mathrm{~cm}$ in Randomised Block Design. The fertilizers were applied in split doses. One third of the entire dose of NPK and vermicompost were applied as basal dressing and remaining two thirds were applied as top dressing at two intervals of thirty days gap with one third of the entire dose at each application. Watering was done as per requirements.

Observations on the number of non wrapper leaves, polar and equatorial diameters of head, plant height, stalk girth, whole weight and yield (whole weight-weight of the non wrapper leaves) were taken replication wise. The shape of head in terms of polar and equatorial diameter and their ratio as shape index were worked out as 
Yield Response Of Cabbage ( Brassica oleraceae var. capitata) cv. Pride Of India To Varying Levels Of suggested by Odland and Noll (1954). The whole weight of head was taken as the weight of the head along with the non-wrapper leaves. The statistical analysis was carried using ANOVA one way test. The critical difference between treatment means was determined by Duncan's test at $p=0.05$.

\section{Results And Discussion}

The yield of cabbage was greatly influenced by the different treatments. The data of the analysis revealed that different levels of NPK and vermicompost has a significant influence on the yield and its attributes. The data presented in Table 1 showed that in all the crop seasons, the maximum number of non-wrapper leaves was observed in $\mathrm{T} 2$ recording a value of 15.00 in both the $1^{\text {st }}$ and $3^{\text {rd }}$ years and the minimum was observed in $\mathrm{T} 1$ in all the years. The number of non wrapper leaves in T2 was shown to increase by $55.28 \%$ over control. On pooled analysis, there was similar trend of significant differences in the number of non wrapper leaves. However T3 and T5 were at par with each other. This may be due to the effect of $\mathrm{N}$ in promoting growth and resulted in more number of leaves. This finding is in agreement with that of Som et al., (1976); Mahendran and Kumar (1997) and Roy (2001).

The polar diameter of head was affected by various treatments. The maximum was found in T4 with a value of $18.67 \mathrm{~cm}$ in the $3^{\text {rd }}$ year and minimum was recorded in $\mathrm{T} 1$ in the $3^{\text {rd }}$ year. There was an increase of $32.69 \%$ in T4 over control. Pooled analysis also revealed the same trend. However, T2 and T3 were at par and also T5 and T6 were at par with each other. The maximum equatorial diameter was observed in T2 $(18.27 \mathrm{~cm})$ in the $3^{\text {rd }}$ year recording a $37.36 \%$ increase over $\mathrm{T} 1$ which recorded a minimum of 13.38 in the $1^{\text {st }}$ year. Pooled analysis also showed similar pattern. However T3, T5 and T6 were at par with each other. The outcome of the investigation revealed that the shape index of heads was not influenced by the various treatments and that heads were normal or spherical in shape. These results are in accordance with that of Morris (1950); Mahendran and Kumar (1997) and Roy (2001).

Table 1: Influence of organic manures and NPK on the yield attributes of cabbage in the three crop seasons 2006-07, 2007-08 \& 2008-09.

\begin{tabular}{|c|c|c|c|c|c|c|c|c|c|c|c|c|c|c|c|c|}
\hline \multirow[t]{2}{*}{$\begin{array}{l}\text { Treat } \\
\text { ment }\end{array}$} & \multicolumn{4}{|c|}{ No. of non wrapper leaves } & \multicolumn{4}{|c|}{ Polar diameter of head $(\mathrm{cm})$} & \multicolumn{4}{|c|}{$\begin{array}{l}\text { Equatorial diameter of head } \\
(\mathbf{c m})\end{array}$} & \multicolumn{4}{|c|}{ Shape index } \\
\hline & $\begin{array}{l}1^{\text {st }} \\
\mathbf{y r}\end{array}$ & $\begin{array}{l}2^{\text {nd }} \\
\text { yr }\end{array}$ & $\begin{array}{l}3^{\text {rd }} \\
y r\end{array}$ & $\begin{array}{l}\text { Pool } \\
\text { ed }\end{array}$ & $\begin{array}{l}\mathbf{1}^{\text {st }} \\
\mathbf{y r}\end{array}$ & $\begin{array}{l}2^{\text {nd }} \\
y r\end{array}$ & $\begin{array}{l}3^{\text {rd }} \\
y r\end{array}$ & $\begin{array}{l}\text { Pool } \\
\text { ed }\end{array}$ & $\begin{array}{l}1^{\text {st }} \\
\mathbf{y r}\end{array}$ & $\begin{array}{l}2^{\text {nd }} \\
\text { yr }\end{array}$ & $\begin{array}{l}3^{\text {rd }} \\
y \mathbf{r}\end{array}$ & $\begin{array}{l}\text { Pool } \\
\text { ed }\end{array}$ & $\begin{array}{l}1^{\text {st }} \\
\text { yr }\end{array}$ & $\begin{array}{l}2^{\text {nd }} \\
\text { yr }\end{array}$ & $\begin{array}{l}3^{\text {rd }} \\
y^{2}\end{array}$ & $\begin{array}{l}\text { Pool } \\
\text { ed }\end{array}$ \\
\hline T1 & $\begin{array}{l}10.0 \\
0\end{array}$ & 9.75 & 9.66 & 9.81 & $\begin{array}{l}14.1 \\
0\end{array}$ & $\begin{array}{l}14.0 \\
9\end{array}$ & $\begin{array}{l}14.0 \\
7\end{array}$ & $\begin{array}{l}14.0 \\
9\end{array}$ & $\begin{array}{l}13.3 \\
8\end{array}$ & $\begin{array}{l}13.4 \\
0\end{array}$ & $\begin{array}{l}13.4 \\
3\end{array}$ & $\begin{array}{l}13.4 \\
1\end{array}$ & 1.04 & 1.05 & 1.04 & 1.05 \\
\hline $\mathrm{T} 2$ & $\begin{array}{l}15.0 \\
0\end{array}$ & $\begin{array}{l}14.7 \\
5\end{array}$ & $\begin{array}{l}15.0 \\
0\end{array}$ & $\begin{array}{l}14.9 \\
2\end{array}$ & $\begin{array}{l}17.5 \\
2\end{array}$ & $\begin{array}{l}17.5 \\
2\end{array}$ & $\begin{array}{l}17.5 \\
2\end{array}$ & $\begin{array}{l}17.5 \\
2\end{array}$ & $\begin{array}{l}18.3 \\
8\end{array}$ & $\begin{array}{l}18.3 \\
9\end{array}$ & $\begin{array}{l}18.4 \\
0\end{array}$ & $\begin{array}{l}18.3 \\
9\end{array}$ & 0.95 & 0.95 & 0.94 & 0.95 \\
\hline T3 & $\begin{array}{l}14.2 \\
5\end{array}$ & $\begin{array}{l}14.0 \\
0\end{array}$ & $\begin{array}{l}14.0 \\
0\end{array}$ & $\begin{array}{l}14.0 \\
8\end{array}$ & $\begin{array}{l}17.3 \\
8\end{array}$ & $\begin{array}{l}17.4 \\
2\end{array}$ & $\begin{array}{l}17.4 \\
6\end{array}$ & $\begin{array}{l}17.4 \\
2\end{array}$ & $\begin{array}{l}17.3 \\
8\end{array}$ & $\begin{array}{l}17.3 \\
8\end{array}$ & $\begin{array}{l}17.3 \\
9\end{array}$ & $\begin{array}{l}17.3 \\
9\end{array}$ & 1.00 & 1.00 & 1.00 & 1 \\
\hline $\mathrm{T} 4$ & $\begin{array}{l}14.7 \\
5\end{array}$ & $\begin{array}{l}14.5 \\
0\end{array}$ & $\begin{array}{l}14.3 \\
3\end{array}$ & $\begin{array}{l}14.5 \\
3\end{array}$ & $\begin{array}{l}18.6 \\
4\end{array}$ & $\begin{array}{l}18.6 \\
5\end{array}$ & $\begin{array}{l}18.6 \\
7\end{array}$ & $\begin{array}{l}18.6 \\
6\end{array}$ & $\begin{array}{l}17.9 \\
0\end{array}$ & $\begin{array}{l}17.8 \\
9\end{array}$ & $\begin{array}{l}17.9 \\
6\end{array}$ & $\begin{array}{l}17.9 \\
2\end{array}$ & 1.03 & 1.04 & 1.05 & 1.04 \\
\hline T5 & $\begin{array}{l}13.5 \\
0\end{array}$ & $\begin{array}{l}13.5 \\
0\end{array}$ & $\begin{array}{l}13.6 \\
6\end{array}$ & $\begin{array}{l}13.5 \\
6\end{array}$ & $\begin{array}{l}18.2 \\
6\end{array}$ & $\begin{array}{l}18.3 \\
4\end{array}$ & $\begin{array}{l}18.3 \\
5\end{array}$ & $\begin{array}{l}18.3 \\
2\end{array}$ & $\begin{array}{l}17.3 \\
7\end{array}$ & $\begin{array}{l}17.3 \\
8\end{array}$ & $\begin{array}{l}17.3 \\
9\end{array}$ & $\begin{array}{l}17.3 \\
8\end{array}$ & 1.05 & 1.05 & 1.05 & 1.05 \\
\hline T6 & $\begin{array}{l}12.7 \\
5\end{array}$ & $\begin{array}{l}12.7 \\
5\end{array}$ & $\begin{array}{l}12.6 \\
6\end{array}$ & $\begin{array}{l}12.7 \\
2\end{array}$ & $\begin{array}{l}18.2 \\
3\end{array}$ & $\begin{array}{l}18.2 \\
5\end{array}$ & $\begin{array}{l}18.2 \\
5\end{array}$ & $\begin{array}{l}18.2 \\
5\end{array}$ & $\begin{array}{l}17.3 \\
3\end{array}$ & $\begin{array}{l}17.3 \\
0\end{array}$ & $\begin{array}{l}17.2 \\
9\end{array}$ & $\begin{array}{l}17.3 \\
1\end{array}$ & 1.04 & 1.05 & 1.05 & 1.05 \\
\hline CD & 1.04 & 1.05 & 1.06 & 1.05 & 0.04 & 0.05 & 0.06 & 0.05 & 0.06 & 0.06 & $\mathbf{0 . 0 5}$ & 0.06 & 0 & 0 & 0.02 & 0.01 \\
\hline $\mathbf{E} \pm$ & & & & 0.83 & & & & 0.75 & & & & 0.80 & & & & 0.02 \\
\hline
\end{tabular}

Table 2 and Table 3 revealed that plant growth and biomass production of cabbage varied significantly with each treatment. Plant growth in terms of plant height and stalk girth and biomass in terms of whole weight and yield (net weight) increased significantly over control. The maximum plant height was recorded in $\mathrm{T} 4(28.65 \mathrm{~cm})$ in the $2^{\text {nd }}$ and $3^{\text {rd }}$ years with a significant increase of $35.91 \%$ over control. The same trend was recorded on pooled analysis. The treatments $\mathrm{T} 5$ and $\mathrm{T} 6$ were at par with each other.

The maximum stalk girth was recorded in $\mathrm{T} 5(3.20 \mathrm{~cm})$ in the 1 st year and minimum was recorded in $\mathrm{T} 1$ of the same year. However, pooled analysis showed a different trend with the maximum being recorded in T4 with a $58.8 \%$ increase over control. The value was also at par with the values of T5 and T6. Reinecke and Visser, (1980) proved that vermicast can promote luxuriant growth of plants. This may be attributed to the presence of plant growth hormones in the cast (Krishnamoorthy and Vajranabhaih, 1986).

The different treatments showed significant differences in the whole weight of the head. The treatment T4 comprising of NPK@70:70:70 kg/ha+V.C@2tons/ha was found to record a maximum value of $2.26 \mathrm{~kg}$ in the $3^{\text {rd }}$ year with a significant increase of $56.94 \%$ over T1. Similar observations were also recorded on pooled analysis. The treatments $\mathrm{T} 2, \mathrm{~T} 5$ and $\mathrm{T} 6$ were at par with each other. 
Yield Response Of Cabbage ( Brassica oleraceae var. capitata) cv. Pride Of India To Varying Levels Of

Table 2: Influence of organic manures and NPK on the plant growth of cabbage in the three crop seasons 2006-07, 2007-08 \& 2008-09.

\begin{tabular}{|c|l|l|c|c|l|l|l|l|}
\hline Treatment & \multicolumn{4}{|c|}{ Plant height $(\mathbf{c m})$} & \multicolumn{4}{c|}{ Stalk girth $(\mathbf{c m})$} \\
\hline & $\mathbf{1}^{\text {st }} \mathbf{y r}$ & $\mathbf{2}^{\text {nd }} \mathbf{y r}$ & $\mathbf{3}^{\text {rd }} \mathbf{y r}$ & $\mathbf{P o o l e d}$ & $\mathbf{1}^{\text {st }} \mathbf{y r}$ & $\mathbf{2}^{\text {nd }} \mathbf{y r}$ & $\mathbf{3}^{\text {rd }} \mathbf{y r}$ & Pooled \\
\hline T1 & 21.11 & 21.08 & 21.08 & 21.09 & 1.98 & 2.00 & 1.99 & 1.99 \\
& & & & & & & & \\
\hline T2 & 26.55 & 26.55 & 26.63 & 26.58 & 3.00 & 2.98 & 2.99 & 2.99 \\
& & & & & & & & \\
\hline T3 & 26.06 & 26.08 & 26.05 & 26.06 & 2.87 & 2.85 & 2.89 & 2.87 \\
\hline T4 & 28.64 & 28.65 & 28.65 & 28.65 & 3.13 & 3.10 & 3.15 & 3.13 \\
\hline T5 & 28.06 & 28.04 & 28.06 & 28.05 & 3.20 & 3.04 & 3.07 & 3.1 \\
\hline T6 & 28.11 & 28.14 & 28.17 & 28.14 & 3.10 & 3.08 & 3.10 & 3.09 \\
\hline CD & $\mathbf{0 . 0 2}$ & $\mathbf{0 . 0 3}$ & $\mathbf{0 . 1}$ & $\mathbf{0 . 0 5}$ & $\mathbf{0 . 0 4}$ & $\mathbf{0 . 4 4}$ & $\mathbf{0 . 0 3}$ & $\mathbf{0 . 1 7}$ \\
\hline SE \pm & & & & $\mathbf{1 3 7 . 4 8}$ & & & & 158.57 \\
\hline
\end{tabular}

Table 3: Influence of organic manures and NPK on biomass production of cabbage in the three crop seasons 2006-07, 2007-08 \& 2008-09.

\begin{tabular}{|c|l|l|l|l|l|l|l|l|}
\hline Treatment & \multicolumn{5}{|c|}{ Whole weight (kg) } & \multicolumn{4}{c|}{ Yield (kg) } \\
\hline & $\mathbf{1}^{\text {st }} \mathbf{y r}$ & $\mathbf{2}^{\text {nd }} \mathbf{y r}$ & $\mathbf{3}^{\text {rd }} \mathbf{y r}$ & Pooled & $\mathbf{1}^{\text {st }} \mathbf{y r}$ & $\mathbf{2}^{\text {nd }} \mathbf{y r}$ & $\mathbf{3}^{\text {rd }} \mathbf{y r}$ & Pooled \\
\hline $\mathrm{T} 1$ & 1.44 & 1.46 & 1.44 & 1.45 & 1.21 & 1.21 & 1.21 & 1.21 \\
\hline $\mathrm{T} 2$ & 2.12 & 2.12 & 2.05 & 2.10 & 1.84 & 1.84 & 1.84 & 1.84 \\
& & & & & & & & \\
\hline $\mathrm{T} 3$ & 2.01 & 2.02 & 2.02 & 2.02 & 1.78 & 1.78 & 1.78 & 1.78 \\
& & & & & & & & \\
\hline T4 & 2.23 & 2.24 & 2.26 & 2.24 & 1.91 & 1.92 & 1.92 & 1.92 \\
\hline T5 & 2.05 & 2.09 & 2.15 & 2.10 & 1.84 & 1.85 & 1.87 & 1.85 \\
\hline T6 & 2.05 & 2.06 & 2.08 & 2.06 & 1.82 & 1.82 & 1.83 & 1.82 \\
\hline CD & $\mathbf{0 . 0 3}$ & $\mathbf{0 . 0 3}$ & $\mathbf{0 . 0 3}$ & $\mathbf{0 . 0 3}$ & $\mathbf{0}$ & $\mathbf{0}$ & $\mathbf{0}$ & $\mathbf{0}$ \\
\hline SE \pm & & & & 11.97 & & & & 10.42 \\
\hline
\end{tabular}

The maximum yield was recorded in $\mathrm{T} 4$ in the $2^{\text {nd }}$ and $3^{\text {rd }}$ years and minimum was recorded in $\mathrm{T} 1$. The yield also showed a significant increase of $58.67 \%$ over control. Pooled analysis revealed similar trend. The values of T2, T5 and T6 were at par with each other. Therefore, vermicompost showed close results with NPK in terms of yield performance in cabbage. Similar findings were also recorded by Bano et.al.,(1996) in radish and brinjal. The magnificent increase in the yield might be attributed to the high resume of carbohydrate (Roy,2001) or to the enhancement in the availability of native and applied macro and micro nutrients (Mahendran and Kumar,1997). Beneficial effects of combined application of organic and inorganic fertilizers in cabbage was also reported by Jothi et al., (1993) and Wange et al.,(1995).

\section{Conclusion}

From the above observations it could be concluded that the different levels of NPK and vermicompost influenced the yield attributing characters and growth and biomass production in cabbage. The outcome of the present investigation clearly indicates the replacement of the harmful chemical fertilizer by the eco-friendly vermicompost. 
Yield Response Of Cabbage ( Brassica oleraceae var. capitata) cv. Pride Of India To Varying Levels Of

\section{Acknowledgement}

The authors acknowledged the financial assistance supported by the Department of Biotechnology,

Government of India during the course of the study.

\section{References}

[1] Ambika, S. R. and Kurian, G. S. (2004) Organic formulations for effective growth and yield in vegetables. J.Curr.Sci. 5(1):41-48.

[2] Bano, K.; Kale, R. D. and Satyavathi, G. P. (1996) Vermicompost as fertilizers for vegetable crops. In: Vermicompost- Crown Jewel of Organic farming. [Radha D. Kale Ed:] Published by N.D. Kale, India.

[3] Edwards, C. A. and Lofty, J. C. (1977) Biology of Earthworms. 2nd. Edn., Chapman and Hall, London: 333.

[4] Ismail, S. A. (2005) The Earthworm Book, Other India Press. Goa, India: 1-80

[5] Jothi, L. J.; Mani, A. K.; Pappiah, C. M. and Rajagoplan, R. (1993) Influence of NPK and Azospirillium on yield of Cabbage. South Indian Horticulture 41: 270-272.

[6] Kale, R.D. (1996) Earthworms- The significant contributors to Organic farming and Sustainable Agriculture. In: Organic farming and Sustainable Agriculture. (Eds.G.K.Veeresh; K. Shivashankar and M.A.Singlachar) Publ. Association for promotion o organic farming. : 52-57.

[7] Krishnamoorthy, R. V. and Vajranabhaih, S. N. (1986) Biological activity of earthworm casts: An assessment of plant growth promoter levels in the casts. Proc Indian Acad Sci (Anim Sci), 95: 341-351.

[8] Lee, K. E. (1985) Earthworms: Their Ecology and Relationships with Soils and Land Use, Academic Press, London: 411.

[9] Mahendran, P. P. and Kumar, N. (1997). Effect of organic manure on cabbage w. Hero (Brassica Oleraceae var. Capitata L.). South Indian Hort. 45(5\&6): 240-243.

[10] Morris, V. S. (1950) Proc. $4^{\text {th }}$ Annual Rio Gransde Valley. Horticulture Society. 33-39.

[11] Odland, M. L. and Noll, C. J. (1954) Vegetable variety trials, Prog. Rep.Pa. Agril. Exp.stn.:114.

[12] Reinecke, A. J. and Visser, F. A. (1980) The influence of agricultural land use practices on the population densities of Allobophora trapezoids and Eisenia rosea in southern Africa. In: Soil Biology as related to land use practices. ( Dindal, D.L.ed) Washington DC: EPA.: $310-324$.

[13] Roy,A.(2001) Effect of different sources of plant nutrients on growth and yield of cabbage (Brassica oleracea var. capitata.L.) M.Sc.(Agri) Thesis, Central agricultural University, Iroisemba, Imphal.

[14] Sinha,R.K.; Valani,D., Chauhan,K. and Agarwal,S.(2010) Embarking on a second green revolution for sustainable agriculture by vermiculture biotechnology using earhworms: Reviving the dreams of Sir Charles Darwin. J.Agric.Biotech.Sustainable Dev. 2(7): 113128.

[15] Som, M. G.; Jana, P. K. and Pal, S. S. (1976) Soil moisture regimes and nitrogen levels on the yield and consumption use of water by cabbage. Veg. Sci.,111: 131-137.

[16] Talashilkar, S. C.; Kadam R. G.; Todkari A. A.; InamdarP.V. and Dhopavkar R.V. (2003) Vermiculture biotechnology, In: Vermiresource Technology Tripathi, G. ed. Discovery Publishing House: 106.

[17] Tomlin, A.D. (1983) The earthworm bait in North America.: 331-338.

[18] Wange, S. S.; Patil,P. L.; Meher, B. B.; Karkeli, M. S. (1995). Response of cabbage to microbial inoculants and incremental levels of nitrogen. J. of Maharastra Agri. University 20(3):429-430. 